\title{
Evaluation of wound healing effect of herbal lotion in albino rats and its antibacterial activities
}

\author{
T. Dons ${ }^{*}$ and S. Soosairaj
}

\begin{abstract}
Background: This particular study emphasis on the in vivo wound healing and in vitro antibacterial activity of herbal lotions preparated from Ethanolic extract of Justicia tranquebariensis, Aloe vera and Curcuma longa.

Methods: Each plant powder $(10 \mathrm{~g})$ was soaked in $30 \mathrm{ml}$ of ethanol in a sterile bottle for $48 \mathrm{~h}$ at $4{ }^{\circ} \mathrm{C}$. Herbal lotion formulation I (10\%) and II (20\%) was prepared. Antibacterial activity by Agar Well diffusion method for three medicinal plant lotions was tested against skin and wound pathogens, like Staphylococcus aureus, Bacillus subtilis, Escherichia coli and Klebsiella pneumoniae. The excision wound model was employed for wound healing activity in albino rats. Healthy albino rats (150-200 g) of either sex were taken for excision wound model. Animals were divided into four groups of six animals in each. The Group 1 is control. The Groups 2 and 3 animals were treated with 10\% and 20\% ointment of herbal lotion and Group 4 animals were treated with Soframycin that served as standard. All animals had free access to pelleted food and water. Temperature was maintained at $23 \pm 1{ }^{\circ} \mathrm{C}$. The results were expressed as mean \pm SEM. Further sample tissues were fixed in $10 \%$ buffered formalin, processed and blocked with paraffin at $40-60{ }^{\circ} \mathrm{C}$, and then sectioned into $5 \mu \mathrm{m}$ thick sections. The significance of differences between the means was analyzed by student's t- test followed by Turkey's test.
\end{abstract}

Results: Complete wound healing was observed with lotion formulation I and II treated rats in 15 days as that of Soframycin ointment. These findings were further confirmed by histological examination of granulation tissue with a lesser amount of collagination and absence of inflammatory cells.

Conclusion: The findings from this research indicates that the ethanol extract of Justicia tranquebariensis, Aloe vera and Curcuma longa are effective in inhibiting the growth of wound associated pathogen and faster the process of wound healing.

Keywords: Justicia tranquebariensis, Curcuma longa, Aloe vera, Lotion, Wound healing and histochemical studies

\section{Background}

Wound is the disruption of cellular and anatomic continuity of living tissue produced by physical, chemical, electrical or microbial insults to the tissue. Wound healing is the dynamic process of regeneration or repair of broken tissue [1]. Normal wound-healing response begins with injury and is a concentrated sequence of events. The healing cascade is activated when platelets aggregate and the release of clotting factors resulting in the deposition of fibrin clot at the site of injury [2]. The fibrin clot serves as a provisional matrix and sets the stage for the subsequent events of healing.

\footnotetext{
*Correspondence: dona.thiraviadoss@gmail.com

Department of Botany, St. Joseph's College, Trichy, India
}

Inflammatory cells also arrive along with the platelets at the site of injury providing key signals known as cytokines or growth factors. The fibroblast is the connective tissue responsible for collagen deposition that is needed to repair the tissue injury. In normal tissues, collagen provides strength, integrity, and structure. When tissues are disrupted following injury, collagen is needed to repair the defect and restore anatomic structure and function [3].

Hence, there is a need for herbal based wound healing agents. Curcuma longa has anti-inflammatory, antimicrobial and wound healing property [4]. Aloe has antiinflammatory activity, increase degree of cross-linking [5] and also used as moisturizing agent. 
The rationale behind the selection of above microbial stains is based on the literature survey as referred below. Staphylococcus aureus and Escherichia coli were the most common causative agent of wound infections [6, 7]. Klebsiella pneumoniae was associated with nosocomial infections burn wound infection and sepsis in surgical wounds [8]. Bacillus subtilis was associated with nosocomial infection and could cause secondary diseases and infections such as bacteremia, septicemia, and wound infection in hospitalized patients, especially patients who had the impaired immune system [9].

In present study herbal lotion was prepared and its feasibility was checked by wound healing activity in albino rats as compared to Soframycin ointment.

\section{Methods}

\section{Plant collection and processing}

Stem of Justicia tranquebariensis, succulent leaves of Aloe vera and rhizome of Curcuma longa were collected from Semmalai hills. Their taxonomic identify was confirmed using local flora [10]. The plants were washed three times in running tap water to remove the soil particles and other unwanted waste materials. Cleaned plants were chopped into small pieces and shade dried at room temperature. The dried plant samples were pulverized using a blender and the powder were collected in a clean glass bottles and stored until further use.

\section{Preparation of NA broth}

Staphylococcus aureus, Bacillus subtilis, Escherichia coli, and Klebsiella pneumoniae were procured from Doctors Diagnostic Centre, Tiruchirappalli and subculture in nutrient broth with the help of sterile inoculation loop. The pure cultured nutrient broth was kept overnight at $37{ }^{\circ} \mathrm{C}$. After that, the culture was maintained in freezer for further use [11].

\section{Preparation of plant extract}

Each plant powder $(10 \mathrm{~g})$ was soaked in $30 \mathrm{ml}$ of ethanol in a sterile bottle for $48 \mathrm{~h}$ at $4{ }^{\circ} \mathrm{C}$. There after the extract was filtered and allowed to evaporate and the residue was weighed. The solvent free dried extract residues were resuspended in ethanol and stored in refrigerator for herbal lotion preparation [12].

\section{Herbal lotion}

Herbal lotion formulation I (10\%) and II (20\%) was prepared by dissolving Justicia tranquebariensis, Aloe vera and Curcuma longa extracts as given in (Table 1). To this Petroleum Jelly and White soft paraffin was added and the mixture was stirred. Petroleum jelly and white soft paraffin, (British Pharmacopoeia, 1988) was used as a hydrocarbon (oleaginous) base.
Table 1 Constituents of herbal lotion

\begin{tabular}{lll}
\hline Ingredients & Formulation I (10\%) (in g) & Formulation II (20\%) (in g) \\
\hline Justicia tranquebariensis & 1 & 2 \\
Aloe vera & 0.75 & 1.5 \\
Curcuma longa & 0.5 & 1 \\
Petroleum Jelly & 6.75 & 13.5 \\
White soft paraffin & 1 & 2 \\
\hline
\end{tabular}

\section{Antibacterial activity by agar well diffusion method}

The prepared lotion was studied for its activity against gram positive bacteria (Staphylococcus aureus, Bacillus subtilis) and gram negative bacteria (Escherichia coli, Klebsiella pneumoniae).

The antibacterial activity of the extracts was determined by agar well diffusion technique. $20 \mathrm{ml}$ of nutrient agar media was transferred into petriplates and they were left undisturbed for $1-2 \mathrm{~h}$. Bacterial culture $(0.5 \mu \mathrm{l})$ was transferred into petriplates using cotton stick and evenly spread with the help of sterile bent glass rod. Cups was made in Petri plates using sterile cork borer having diameter of $6 \mathrm{~mm}$ and each formulation was added into well. Then bacterial plates were incubated at $37{ }^{\circ} \mathrm{C} 24 \mathrm{~h}$ [13]. Antibacterial activity was determined by measuring the zone of inhibition around each well using zone reader [14]. Measured inhibition zones were recorded as mean diameter in $\mathrm{mm}$.

\section{Evaluation of in vivo wound healing activity Study setting}

Ethical approval to the study was obtained from the Srimad Andavan Arts and Science College institutional animal ethics committee (Vide No. SAC/IAEC/BC/2016/Ph.D-001) (Appendix - I). Albino rats (150-200 g) were housed in standard plastic rat cages with stainless steel coverlids and wheat straw was used as bedding material. The animals were kept at the animal house of Department of Biochemistry, Srimad Andavan Arts and Science College, Tiruchirappalli. All animals had free access to pelleted food and water. Temperature was maintained at $23 \pm 1{ }^{\circ} \mathrm{C}$.

The animals were divided in to four groups as given below. Each group consisted of six animals each.

- Group I - Normal Excision wounded animals without treatment

- Group II - Normal Excision wounded animals with Low dose (10\%) treated for 15 days.

- Group III - Normal Excision wounded animals with High dose (20\%) treated for 15 days.

- Group IV - Normal Excision wounded animals with Standard Drug Soframycin treated for 15 days.

Excision wound model The rats weighing (150 to $200 \mathrm{~g}$ ) were selected and their hairs from dorsal thoracic central 
region were shaved after anaesthetized to a diameter of $30 \mathrm{~mm}$ with the aid of rizor blades. The anticipated area of the wound was marked on the shaved skin. Skin wound were created with aid of toothed forceps, surgical blades and pointed scissors. The wound was cleaned with cotton swab soaked in alcohol.

The two herbal formulations and Soframycin ointment were applied on wound once daily for 15 days starting from the first day of wounding. Wound contraction was measured for 15 days at interval of 2 days [15]. Contraction which mainly contributes for wound closure was studied by tracing the raw wound area on transparent paper every alternate day till wounds were completely covered with epithelium. These wound tracings were retraced on a millimeter scale graph paper, to determine the wound area. Wound contraction (WC) was calculated as a percentage change in the initial wound size i.e.

Percentage Wound Closure $=\frac{(\text { Initial wound size-specific day wound size })}{\times 100 \quad \text { Initial Wound size }}$

Epithalization period was monitored by noting the number of days required for Escher to fall away, leaving no raw wound behind.

Histopathology study of wounds The healing tissues from all groups of animals were obtained on 15th day and processed for histological study. Sample tissues were fixed in $10 \%$ buffered formalin, processed and blocked with paraffin at $40-60{ }^{\circ} \mathrm{C}$, and then sectioned into $5 \mu \mathrm{m}$ thick sections with the help of microtome section and stained with hematoxylin-eosin and observed under microscope for any histological changes [16]. The different animal groups were assessed and the results were compared with control groups.

Statistical analysis The results were expressed as mean \pm SEM. The significance of differences between the means was analyzed by student's t- test followed by Turkey's test. A $P$-value $<0.05$ was considered significant.

\section{Results and discussion}

\section{Antibacterial activity of plant lotion}

The lotions I \& II exhibited excellent antibacterial activity against all the selected bacteria. Among the four test organisms E. coli, and Klebsiella pneumoniae were inhibited by formulation I and II. Moderate inhibition was noticed against Staphylococcus aureus and Bacillus subtilis. It was observed that, inhibitory action was highest for gram negative bacteria, followed by gram positive bacteria Table 2 .

J. tranquebariensis; A. vera and C. longa were part of the traditional system of medicine for treating skin conditions by topical applications onto the affected area [17-19]. All
Table 2 Results of antibacterial activity of herbal lotion by agar well diffusion method

\begin{tabular}{lll}
\hline Test organism & \multicolumn{2}{l}{ Zone of Inhibition in $\mathrm{mm}^{* *}$} \\
\cline { 2 - 3 } & $10 \%$ & $20 \%$ \\
\hline Staphylococcus aureus & $10,11,13$ & $12,13,15$ \\
Bacillus subtilis & $10,12,13$ & $11,13,15$ \\
E. coli & $10,11,12$ & $12,14,15$ \\
Klebsiella pneumoniae & $11,12,13$ & $12,13,14$ \\
\hline
\end{tabular}

**Zone measurement

chronic wounds were colonized by bacteria, with low levels of bacteria being beneficial to the wound healing process. Wound infection was detrimental to wound healing, but the diagnosis and management of wound infection was controversial, and varies between clinicians. There was increasing recognition of the concept of critical colonization or local infection, when wound healing may be delayed in the absence of the typical clinical features of infection. The progression from wound colonization to infection depends not only on the bacterial count or the species present, but also on the host immune response, the number of different species present, the virulence of the organisms and synergistic interactions between the different species [20]. There was increasing evidence that bacteria within chronic wounds lived within communities, in which the bacteria were protected from host defences and develop resistance to antibiotic treatment.

An appreciation of the factors affecting the progression from colonization to infection could help clinicians with the interpretation of clinical findings and microbiological investigations in patients with chronic wounds. An understanding of the physiology and interactions within multi-species wound may aid the development of more effective methods of treating infected and poorly healing wounds. The emergence of consensus guidelines has helped to optimize clinical management [21].

\section{Wound healing activity}

In excision wound study, wound contraction rate was identical to the ointment and the herbal formulations (I and II). Complete healing was observed in 14th day in all treated groups Table 3 while untreated group

Table 3 Rate of Wound Contraction and Epithelialization in experimental animals

\begin{tabular}{llll}
\hline Groups & \multicolumn{2}{l}{ Wound Contraction $(\mathrm{cm})$} & \multirow{2}{l}{$\begin{array}{l}\text { Rate of } \\
\text { Epithelialization (Days) }\end{array}$} \\
\cline { 2 - 3 } & Oth Day & 15th Day & \\
\hline Group I & $2.08 \pm 0.06$ & $1.62 \pm 0.05$ & $15.50 \pm 0.56$ \\
Group II & $2.15 \pm 0.02$ & $1.23 \pm 0.02$ & $10.33 \pm 0.42$ \\
Group III & $2.13 \pm 0.05$ & $0.62 \pm 0.04$ & $6.83 \pm 0.31$ \\
Group IV & $2.17 \pm 0.03$ & $0.37 \pm 0.04$ & $4.50 \pm 0.34$ \\
\hline
\end{tabular}


(control) and group IV (cream base) animals took more than 15 days for healing of wounds Fig. 1.

There was a significant increase in percentage of contractibility from day five onwards in herbal lotion treated rats when compared with control rats. The wound contracting ability of animals treated with ointment containing $(20 \% \mathrm{w} / \mathrm{w})$ herbal lotion was found to be significantly higher $(P<0.001)$ on 15 th day when compared to the control group. A better healing pattern and reduction in period of epithalization was observed in herbal lotion $20 \% \mathrm{w} / \mathrm{w}$ treated group.

Results obtained in the present study suggested that treatment of excision wounds with herbal lotion of J.tranquebariensis, A. vera and C. longa has accelerated the wound healing process. The results showed that Soframycin increased the collagen content of the skin and contributed to wound strength. The wound healing potential of the herbal lotion may be attributed to the presence of a mixture of phytoconstituents including flavonoids and tannins [22].

Therapeutic use of medicinal plants was an alternative health care option for those living in rural areas. Dependence on medicinal plants by the rural people was governed by economic factors, ease of availability and the strong belief in the plant remedies. The use of medicinal plants for treating various ailments ranging from acute to chronic conditions has become a way of life for many indigenous people in rural communities. Based on regular usage, many indigenous people were familiar with the different uses, preparations and identification of medicinal plants. Traditional herbalists and herb-sellers were the main sources of distributing information and prescriptions on medicinal plant remedies in rural communities [23].

The histopathological studies revealed Fig. 2 that the wounds treated with herbal lotion $(20 \%)$ showed a discontinuous epidermis, with mild vacuolization and less amount of collagination and absence of in inflammatory cells. The rats treated with $(10 \%)$ herbal lotion showed extensive necrosis and collagination with disturbed epidermis. The Soframycin treated animals showed hyper granulation and evidences of inflammatory cells. Restoration of adnexa, and extensive fibrosis and collagen tissue within the dermis observed. The control group of rats showed normal histopathological architecture.

The maturation and remodeling phase of wound healing has cell population decreased and collagen deposition will be increased in granulation tissues which form

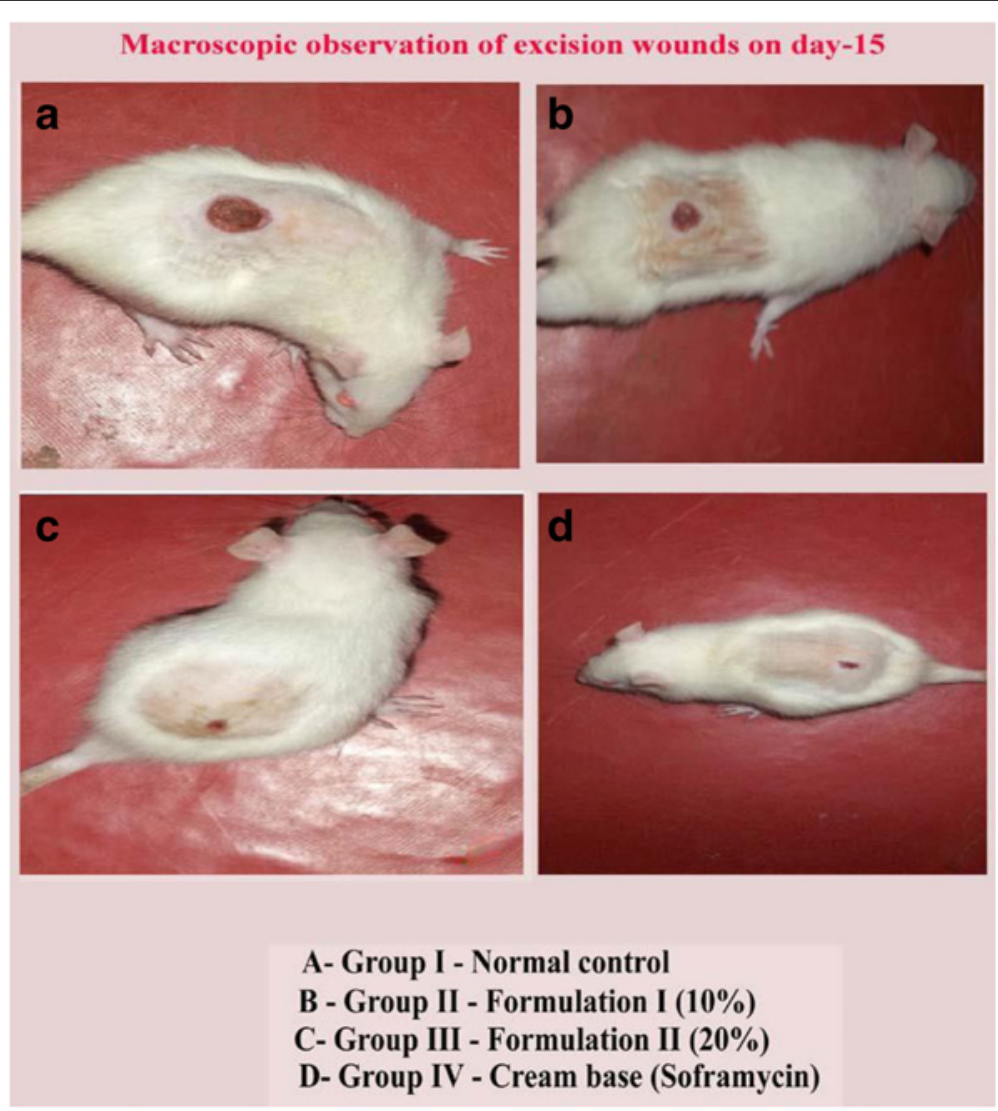

Fig. 1 Photographical representation of wound treatment 


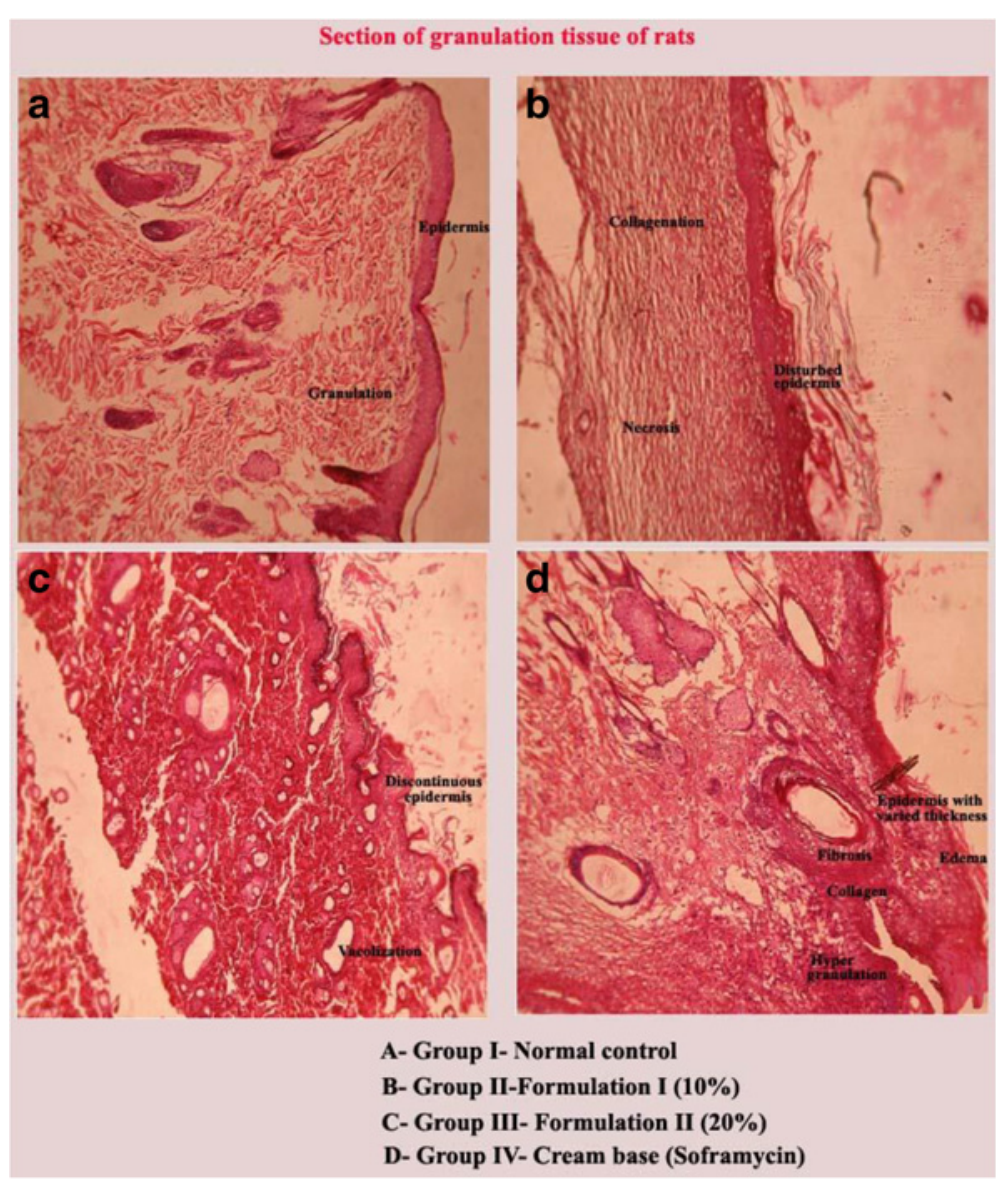

Fig. 2 The Histopathological studies of granulated tissue

the scar. The Fig. 2 shows the histopathological studies of granulated tissue from control to treated group (GROUP-I, GROUP-II GROUP-III GROUP-IV). The hematoxylin and eosin staining were used for the complete loss of collagen and the same was observed in group-1 and group-3. The Group-3 (20\%) dose resulted with significant wound-healing activity by decreasing period of vacuolization formation of granulation tissue. The synthesis of collagen by increased rate of wound contraction was compared to the control animals. Accumulation of inflammatory cells was observed in group-4, compared to treated groups of 2 and 3where the inflammatory cells were absent.

Wounds were physical injuries that resulted in an opening or break of the skin. The most common symptoms of wounds were bleeding, loss of feeling or function below the wound site, heat and redness around the wound, painful or throbbing sensation, swelling of tissue in the area and pus like drainage [24]. Proper healing of wounds was essential for the restoration of disrupted anatomical continuity and disturbed functional status of the skin. It was a product of the integrated response of several cell types to injury.
This process was a complex phenomenon and it mainly comprises of 3 phases: inflammatory phase, proliferative phase and maturational or remodeling phase. The inflammatory phase was characterized by haemostasis and inflammation. Proliferative phase was followed by epithelialization, angiogenesis and collagen deposition. In the maturation phase, the wound underwent contraction resulting in a smaller amount of apparent scar tissue [25-27]. Granulation tissue formed in the final part of the proliferative phase after the topical application of herbal lotion at both low (10\%) and high $(20 \%)$ was composed of collagen and epidermis. The high dose $20 \%$ herbal lotion treated animals showed better results than the reference drug Soframycin treated group though both the dose of herbal lotion treated group showed a significant increase in hydroxyproline content. Collagen was composed of hydroxyproline and amino acids. Hydroxyproline has been used as a biomarker for tissue collagen and the collagen was the major components which supports and strengthen the extracellular tissue [28].

The enhanced capacity of wound healing with the plant was on the basis of anti-inflammatory effects of the plant 
that were well documented in the literature [29]. Study on animal models showed enhanced rate of wound contraction and drastic reduction in healing time than control, which might be due to enhanced epitheliasation. Many studies indicated that plant products were potential agents for wound healing and were largely preferred because of the absence of unwanted side effects and their effectiveness [30]. Any agent who accelerates the above processes was a promoter of wound healing. The application of medicinal concoctions from plants to treat skin lesions, in particular wounds had a long tradition. Plants with wound healing activity have been reported and experimentally studied on various animal models to reveal the most active promising compounds [31].

\section{Conclusion}

All the above results indicate the effectiveness of herbal lotions in enhancing wound healing activities. The herbal lotion prepared from extract of Justicia tranquebariensis, Curcuma longa, and Aloe vera showed marked reduction in wound area in comparison to control group when examined for wound healing activity by topical application in albino rat.

\section{Abbreviations \\ \%: Percentage; ${ }^{0} \mathrm{C}$ : Degree Celsius; C: Celsius; g: Gram; hrs: Hours; i.e.: id est.; ml: Millilitre; mm: Millimolar; NA: Nutrient agar; w/w: Weight per Weight; wC: Wound Contraction; $\mu$ l: Microlitre}

\section{Acknowledgements}

The authors are thankful to the management Professors Agnel Arul John, and Ramesh Kannan, Department of Biochemistry of Srimad Andavan Arts and Science College and for providing facilities to carry out this work. We are also thankful to Dr. Karthik Mohan, and Dr. Benno Susai, Department of Biochemistry, St. Joseph's College, for their help in histopathology.

1. Dr. N. Agnel Arul John

Assistant Professor.

Department of Biochemistry.

Srimad Andavan Arts and Science College.

Trichy-2, India.

2. Dr. N. Ramesh Kannan

Assistant Professor.

Department of Biochemistry.

Srimad Andavan Arts and Science College.

Trichy, India.

3. Dr. Karthik Mohan

Assistant Professor.

Department of Biochemistry.

St. Joseph's College.

Trichy-2, India.

4. Dr. Benno Susai

Assistant Professor.

Department of Biochemistry.

St. Joseph's College.

Trichy-2, India.

\section{Funding}

This study was not funded by any funding agency.

\section{Availability of data and materials}

Not applicable. Reason - All data were incorporated in the article as table, figure etc.

\section{Authors' contributions}

TD - Major part of the research work was done. SS - Monitored the progress and edited the full text manuscript. Both authors read and approved the final manuscript.

Ethics approval and consent to participate

"Not applicable" in this section.

Consent for publication

There is "not applicable" in this section.

\section{Competing interests}

The authors declare that they have no competing interests.

\section{Publisher's Note}

Springer Nature remains neutral with regard to jurisdictional claims in published maps and institutional affiliations.

Received: 31 October 2017 Accepted: 29 January 2018

/ Published online: 06 March 2018

\section{References}

1. Farahpour MR, Habibi M. Evaluation of the wound healing activity of an ethanolic extract of Ceylon cinnamon in mice. Vet Med. 2012;57:53.

2. Eppley BL, Woodall JE, Higgins J. Platelet quantification and growth factor analysis from platelet-rich plasma: implications for wound healing. Plast Reconstr Surg. 2004;114:1502-8.

3. Madhava Chetty K, Sivaji K, Tulasirao K. Flowering plants of Chittor District, Andhra Pradesh. Tirupati, India: Students offset printers; 2008. p. 277.

4. Ukil A, Maity S, Karmakar S, Datta N, Vedasiromoni JR, Das PK. Curcumin, the major component of food flavour turmeric, reduces mucosal injury in trinitrobenzene sulphonic acid-induced colitis. Br J Pharmacol. 2003;139: 209-18.

5. Chithra P, Sajithal GB, Chandrakasan G. Influence of aloe vera on collagen characteristics in healing dermal wound in rats. Mol Cell Biochem. 1998;181: 71-6.

6. Bagdonas R, Tamelis A, Rimdeika R. Staphylococcus aureus in the surgery of burns. Medicina. 2003;39:1078-81.

7. Roesch M, Perreten V, Doher MG, Schaeren W, Schallibaum M, Blum JW. Comparison of antibiotic resistance of udder pathogens in dairy cows kept on organic and on conventional farms. J Dairy Sci. 2006;89:989-97.

8. Schwarz S, Chaslus-Dancla E. Use of anticrobials in veterinary medicine and mechanisms of resistance. Vet Res. 2001;32:201-25.

9. Azizi H, Saleh F, Khelrandish F, Azizi M. Molecular diagnosis and characterization of Bacillus subtilis isolated from burn wound in Iran. Res. Mol Med. 2014;2:40-4.

10. Matthew KM. The Flora of Tamil Nadu Carnatic. The Rapinet HerbariuM, St Joseph's College. 1983; 1-3, Tiruchirapalli, India.

11. Kamal A, Swapna P, Shetti RV, Shaik AB, Narasimha Rao MP, Gupta S. Synthesis, biological evaluation of new oxazolidino-sulfonamides as potential antimicrobial agents. EurJMedChem. 2013;62:661-9.

12. Sebastian S, Thiraviadoss D. Spectral and antibacterial studies on some ethnobotanically important medicinal plants used by Thottianaickans of Semmalai. Indo Am J Pharm Res. 2015;5:2617-25.

13. Pesaramelli K, Vellanki J, Keerthi DV, Chaitanya SK. Evaluation of antibacterial activity of herbs. Int Res J Pharm. 2012;3:230-2.

14. Killedar SG, Harinath N. Antimicrobial and phytochemical screening of different leaf extracts of memecylon umbellatum burm. Int Res J Pharmacy. 2012;3:188-92.

15. Biswas TK, Maity LN, Mukherjee B. Wound healing potential of Pterocarpus Santalinus Linn: a pharmacological evaluation. International journal of low extreme. Wounds. 2004;3:143-50.

16. Sadaf F, Saleem R, Ahmed M, Ahmad SI, Navaid-ul-Zafar N. Healing potential of cream containing extract of Sphaeranthus indicus on dermal wounds in Guinea pigs. J Ethnopharmacol. 2006;107:161-3.

17. Agarry OO, Olaleye MT, Bello-Michael CO. Comparative antimicrobial activities of Aloe vera gel and leaf. Afr J Biotechnol. 2005:4:1413-4.

18. Jagtap NS, Khadabadi SS, Ghorpade DS, Banarase NB, Naphade SS. Antimicrobial and antifungal activity of Centella Asiatica (L.) urban, Umbiliferaceae. Research J Pharm Tech. 2009;2:328-30. 
19. Santosh T, Patro MK, Bal AK, Choudhury A. Langerhans cell Histiocytosis on fine NeedleAspiration cytology: a report of 2 cases and review of literature. Orthop Muscul Syst. 2015;4:1-3.

20. Geraint Rogers B, Mary Carroll P, Kenneth BD. Studying bacterial infections through culture-independent approaches. J Medi Micro. 2009;58:1401-18.

21. Edwards R, Harding K. Bacteria and wound healing. Curr Opin Infect Dis. 2004;12(2):91-6

22. Nayak BS, Sandiford S, Maxwell A. Evaluation of the wound-healing activity of ethanolic of Morinda Citrifolia L. leaf. Evid Based Complement Alternat Med. 2009;6:351-6.

23. Matsiliza B, Barker NPA. Preliminary survey of plants used in traditional medicine in the Grahamstown area. S Afr J Bot. 2001;67:177-82.

24. Gerald C, Walker MW, Criscione L, Gustafson EL, Batzl-Hartmann C, Smith KE, Vaysse P, Durki MM, Laz TM, Linemeyer DL, Schaffhauser AO, Whitebread S, Hofbauer KG, Taber RI, Branchek TA, Weinshank RLA. Receptor subtype involved in neuropeptide-Y-induced food intake. Nature. 1996;382:168-71.

25. Phillips GD, Whitehe RA, Kinghton DR. Initiation and pattern of angiogenesis in wound healing in the rats. Am J Anat. 1991;192:257-62.

26. Baie SH, Sheikh K. The wound healing properties of Channastriatus-cetrimide cream - wound contraction and glycosaminoglycan measurement. J Ethnopharmacol. 2000;73:15-30.

27. Bonner J. Scar wars. Chem Ind (Lond). 2000;23:770-3.

28. Pattanayak SP, Sunita P. Wound healing, anti-microbial and antioxidant potential of Dendrophthoe falcata (L.f) Ettingsh. J Ethnopharmacol. 2008;120: $241-7$.

29. Sarada DVL, Geethalakshmi R, Sakravarthi C, Kritika T, Arul Kirubakaran M. Evaluation of antioxidant and wound healing potentials of Sphaeranthus amaranthoides Burm, f. Biomed Res Int. 2013:1-7.

30. Rashed H, Hesse R, DJW P. Origin of unusually thick ice-proximal Heinrich layers $\mathrm{H} 1$ to H3 in the northwest Labrador Sea. Earth Planet Sci Lett. 2003; 208:319-36.

31. Abu-Al-Basal M. The Influence of Some Local Medicinal Plant Extracts on Skin Wound Healing Activity; Evaluated by Histological and Ultra-Structural Studies. Ph.D. Thesis, University of Jordan, Amman, Jordan. 2001.

\section{Submit your manuscript to a SpringerOpen ${ }^{\circ}$ journal and benefit from:}

- Convenient online submission

- Rigorous peer review

- Open access: articles freely available online

- High visibility within the field

- Retaining the copyright to your article

Submit your next manuscript at $\boldsymbol{s p r i n g e r o p e n . c o m ~}$ 